\title{
PERAN KUALITAS PELAPORAN KEUANGAN DAN BUDAYA ORGANISASI DALAM MEMITIGASI PERSEPSI KORUPSI
}

\author{
Dr. Agustinus Salle, SE, M.Ec
}

Alfiana Antoh, SE, M.Si

\begin{abstract}
Our study contributes by providing a new insight into the relationship between the quality of financial reporting with perceptions of corruption and how the relationship is moderated by organizational culture. In this article we argue that good quality of financial reporting will reduce perceptions of corruption and a strong organizational culture will further reduce perceptions of corruption. Data was collected by distributing questionnaires to 100 students of the Cenderawasih University Post-graduate program who were local government employees and were processed using moderated regression analysis (MRA). The result support the argument that organizational culture negatively influences perceptions of corruption while the effect of financial reporting quality and the influence of organizational culture moderation on perceptions of corruption are not supported. Finding related to the influence of organizational culture indicate that when there are values, norms and beliefs that are both applied within an organization, members of the organization will behave in accordance with these guidelines and will ultimately reduce the possibility of fraud.
\end{abstract}

Keywords: Quality of Financial Reporting, Organizational Culture, Perception of Corruption, Local Government

\section{PENDAHULUAN}

Korupsi berdampak luas pada seluruh lapisan masyarakat. Pellegrini dan Gerlagh (2004) menegaskan bahwa korupsi adalah fenomena yang meluas yang mempengaruhi semua masyarakat dengan derajat yang berbeda, pada waktu yang berbeda. Tavits (2010) menemukan bahwa terdapat persepsi tingkat korupsi yang tinggi di Negara "underdeveloped" dan terdapat tendensi peningkatan korupsi di Negara maju (developed countries). Hal tersebut menunjukan bahwa walaupun telah dilakukan beragam cara pencegahan korupsi baik dengan penetapan regulasi anti korupsi maupun upaya-upaya peningkatan kesadaran moral tentang bahaya korupsi namun belum dapat mengurangi tingkat korupsi secara signifikan. Pada survey yang dilakukan oleh oleh Berlin-based Transparency International, Indonesia berada pada peringkat 37 dalam Indeks Persepsi Korupsi (CPI) 2016. Fenomena di Indonesia menunjukan "Tahun 2004-2017 terdapat 392 Kepala Daerah tersangkut hukum, jumlah terbesar adalah korupsi sejumlah 313 kasus," diungkapkan Mendagri (www.jawapos.com). 
Korupsi khususnya pada organisasi pemerintahan merupakan salah satu indikator bahwa pengelolaan keuangan yang dilakukan oleh pemerintah belum dapat dijalankan dengan baik. Berbeda dengan organisasi swasta yang bermotif profit, pengelolaan keuangan pemerintah lebih ditujukan pada fungsi akuntabilitas (pertanggungjelasan) kepada masyarakat dalam rangka pencapaian kesejahteraan masyarakat. Salah satu media akuntabilitas pemerintah adalah pelaporan keuangan. Pelaporan keuangan yang berkualitas dapat menjadi salah satu barometer pengelolaan keuangan pemerintah yang baik yang tentu saja ditunjukan dengan tingkat penyalanggunaan keuangan (korupsi) yang rendah. Di Indonesia, terdapat peningkatan opini hasil pemeriksaan Badan Pemeriksa Keuangan (BPK) terhadap Laporan Keuangan Pemerintah Daerah (LKPD). Ikhtisar Hasil Pemeriksaan I (IHPS I) Tahun 2017 memuat hasil pemeriksaan atas 537 Laporan Keuangan Pemerintah Daerah (LKPD) dari 542 LKPD Tahun 2016 yang wajib diserahkan. Terhadap 537 LKPD Tahun 2016 tersebut, BPK memberikan 375 opini WTP (70\%), 139 opini WDP (26\%), dan 23 opini TMP (4\%). Apabila dibandingkan dengan capaian tahun 2015, LKPD yang mendapatkan opini WTP meningkat sebesar 12 persen dari 58\% pada tahun 2015 menjadi 70\% pada tahun 2016. Kenaikan opini WTP tersebut menunjukkan kenaikan kualitas LKPD. (www.bpk.go.id).

Kedua kondisi di atas menunjukan fenomena yang bertolakbelakang, pada satu sisi terdapat peningkatan kualitas laporan keuangan yang ditunjukan dengan peningkatan opini BPK sedangkan pada sisi lainnya terdapat peningkatan temuan jumlah kasus korupsi khususnya pada pejabat pemerintah daerah. Peningkatan opini yang menunjukan kualitas laporan keuangan semakin baik yang mencerminkan peningkatan kualitas pengelolaan keuangan pemerintah (pusat dan daerah) seharusnya diikuti dengan penurunan jumlah kasus korupsi.

Riset sebelumnya tentang korupsi sebagian besar meneliti korupsi dan pengaruhnya terhadap kinerja organisasi terutama kinerja finansial perusahaan antara lain : Athanasouli and Sklia ( 2012), Gaviria (2002), Faruq dan Webb (2013), Sahakyan and Stiegert (2012), 
Teal, F. and J. McArthur (2002) dan menggunakan Corruption Perception Indeks (CPI) sebagai ukuran korupsi (Atuilik (2016), Heywood (2009)). Riset-riset tersebut juga lebih banyak meneliti dalam korupsi pada level negara dan level organisasi (Davis and Ruhe (2003), Goel et al (2016), Schmidt and Prytula (2017)) sedangkan riset pada level individu terutama persepsi tentang korupsi (perceived corruption) dalam hubungannya dengan penilaian tentang kualitas pelaporan keuangan sejauh pengetahuan penulis belum pernah dilakukan. Riset sebelumnya dilakukan oleh Kimbro (2002) yang menguji hubungan korupsi dengan peran akuntansi dan kualitas laporan keuangan dilakukan pada level antar negara dan bukan persepsi individu.

Faktor lainnya yang sangat mempengaruhi individu di dalam organisasi adalah budaya organisasi dimana individu bergabung. Tidak dapat dipungkiri bahwa budaya organisasi sangat mempengaruhi sikap dan tindakan anggota organisasi, anggota organisasi yang baru akan cenderung berusaha menyesuaikan diri dengan lingkungan organisasi yang dimasukinya. Riset yang menguji hubungan budaya dengan korupsi masih sangat terbatas jumlahnya khususnya hubungan antara korupsi dan budaya organisasi. Salah satu riset yang menguji hubungan antara budaya organsasi dan korupsi dilakukan oleh Braje dan Galetic (2014). Hasilnya menunjukan bahwa budaya korupsi yang kuat dalam organisasi berhubungan positif dan signifikan dengan korupsi. Riset ini menguji peran kualitas pelaporan keuangan dan budaya organisasi dalam mengurangi persepsi korupsi.

\section{LANDASAN TEORI DAN PENGEMBANGAN HIPOTESIS}

\section{Korupsi}

Terdapat beragam definisi tentang korupsi dan sulit didefinisikan secara universal, namun menurut kamus Weber secara sederhana korupsi diartikan sebagai suap atau transaksi tidak jujur semacam itu. Definisi korupsi lainnya yang paling umum digunakan adalah penyalahgunaan jabatan publik untuk 'keuntungan ekonomi pribadi' (RoseAckerman,1999 dalam Markovska, 2007). 
Sakahyan dan Trieger (2013) menyatakan bahwa korupsi paling sering didefinisikan sebagai menggunakan fasilitas publik untuk keuntungan pribadi. Dari sudut pandang ekonomi neoklasik, korupsi merupakan peluang unilateral bagi agen ekonomi individu untuk memperkaya diri mereka melalui aktivitas illegal . Korupsi hadir dalam berbagai bentuk di dalam atau di seluruh hirarki struktur lembaga pemerintah (publik-publik), antar lembaga pemerintah dan sektor swasta (swasta - publik), dan melintasi perbatasan nasional (internasional). Korupsi muncul di hampir semua bentuk lokal, negara bagian / provinsi, dan pemerintah pusat. Umumnya, untuk praktik korupsi seperti suap, pemerasan, dan nepotisme , tiga komponen diperlukan: (1) lingkungan yang menguntungkan, (2) agen yang memiliki hak kontrol, dan (3) agen yang bersedia membayar untuk tindakan (atau tidak bertindak) dari agen yang memiliki hak kontrol.

Korupsi memiliki banyak bentuk seperti: penerimaan uang dan imbalan lainnya pemberian kontrak, pelanggaran prosedur untuk memajukan kepentingan pribadi, suap dari program pengembangan atau perusahaan multinasional, pembayaran untuk dukungan legislatif, pengalihan sumber daya publik untuk penggunaan pribadi, menghadapkegiatan ilegal, campur tangan dalam proses peradilan, nepotisme, pencurian umum, overpricing, membangun proyek yang tidak ada, dan pengumpulan pajak dan penipuan penilaian pajak (United Nations, (1990), dalam Mashali (2012).

Korupsi di dalam penelitian ini lebih dipahami sebagai persepsi individu tentang tindakan penyalahgunaan fasilitas maupun jabatan publik untuk kepentingan pribadi (perceived corruption).

\section{Kualitas Pelaporan Keuangan}

Agar manfaat dan tujuan penyajian laporan keuangan dapat dipenuhi maka informasi yang disajikan harus merupakan informasi yang bermanfaat bagi pihak yang berkepentingan dengan informasi tersebut. Mengatakan bahwa informasi harus bermanfaat bagi para 
pemakai sama saja dengan mengatakan bahwa informasi harus mempunyai nilai (Suwardjono, 2005).

FASB dalam Statement of Financial Accounting Concepts No.2 "Qualitative Characteristics of Accounting Information," mengindikasikan bahwa relevansi dan keandalan merupakan dua kualitas utama dengan elemen-elemennya yang berhubungan, sedangkan komparabilitas dan konsistensi disajikan sebagai kualitas sekunder dan interaktif.

Jonas dan Blanchet (2000) menyatakan diskusi tentang kualitas tidak hanya terbatas pada laporan keuangan saja namun juga secara luas pada pelaporan keuangan. Pelaporan keuangan bukan hanya merupakan hasil akhir namun juga merupakan sebuah proses, kualitas dari pelaporan keuangan sangat tergantung pada kualitas setiap prosesnya.
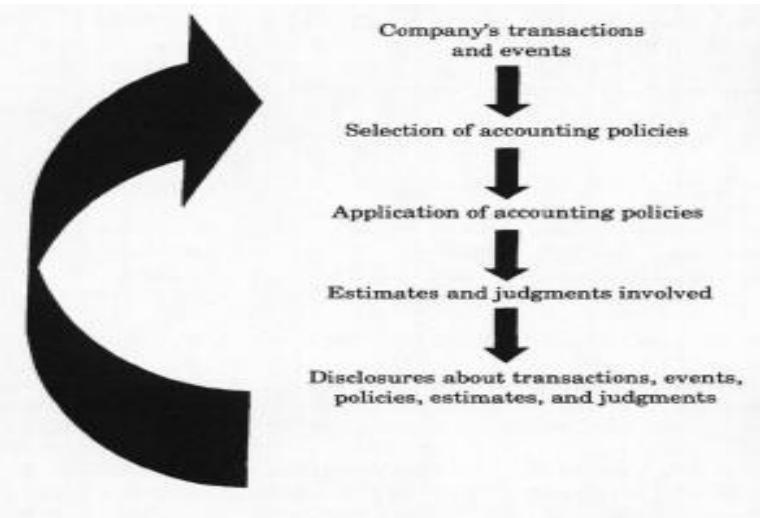

Gambar 1

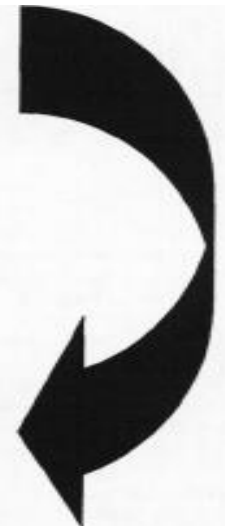

The Financial-Reporting Process

Sumber : Jonas and Blanchet (2000)

Dari gambar 1 terlihat bahwa proses akuntansi yang diawali dari analisis transaksi dan kejadian ekonomi hingga tahap akhir yaitu pengungkapan semua informasi yang berguna dalam pengambilan keputusan harus dilaksanakan dengan baik sehingga dapat menghasilkan pelaporan keuangan yang berkualitas.

Secara khusus pada pelaporan keuangan pemerintah di Indonesia, Kerangka Konseptual Akuntansi Pemerintahan (KSAP,2010) menyatakan karakteristik kualitatif laporan keuangan adalah ukuran-ukuran normatif yang perlu diwujudkan dalam informasi akuntansi sehingga dapat memenuhi tujuannya. Terdapat empat karakteristik prasyarat normatif yang diperlukan agar laporan keuangan pemerintah dapat memenuhi kualitas yang dikehendaki 
yaitu relevan, andal, dapat dibandingkan dan dapat dipahami. Informasi dikatakan relevan apabila: Memiliki manfaat umpan balik (feedback value), manfaat prediktif (predictive value ), tepat waktu, dan lengkap. Informasi yang andal memenuhi karakteristik penyajian jujur, dapat diverifikasi (verifiability), netral, dapat dibandingkan dan dapat dipahami.

\section{Agency Theory}

Jensen and Meckling (1976) menyatakan bahwa hubungan keagenan adalah sebuah kontrak antara manajer (agent) dengan pemegang saham (principal). Untuk konteks organisasi pemerintah, rakyat merupakan prinsipal yang memberikan kewenangan kepada pemerintah sebagai agen. Rakyat merupakan pembayar pajak yang mempercayakan sumberdayanya kepada pemerintah untuk dikelola dalam rangka peningkatan kesejahteraan masyarakat (society walfare). Ketika pemerintah tidak menggunakan sumber daya yang ada sebesar-besarnya bagi kemakmuran rakyat yang bisa saja disebabkan oleh perilaku memanfaatkan jabatan ataupun sumber daya publik bagi kepentingan pribadi (managerial opportunistic behavior) maka kepentingan masyarakat sebagai principal dikorbankan. Dalam pelaksanakaan tugasnya, pemerintah wajib melaporkan pelaksanaan tugasnya kepada masyarakat melalui DPR/DPRD sebagai representasi rakyat. Salah satu bentuk pertanggungjawaban pemerintah kepada masyarakat dalam bidang keuangan adalah menyajikan laporan keuangan pemerintah.

\section{Persepsi}

Siegel and Marconi (1989:36) menyatakan " perception is how people see or interpret events, objects, and people. People act on the basis of their perceptions regardless of whether those perception accurately or inaccurately reflect reality..... One person's description of reality may be far from another person's description .

Berdasarkan definisi di atas dapat disimpulkan bahwa persepsi adalah proses memilih, mengorganisasi dan mengintepretasikan stimulus menjadi gambaran yang berarti dan koheren. Persepsi berbeda antar pribadi karena penerima sensor individual dapat berfungsi berbeda namun biasanya karena berbeda predisposisi. Perasaan seseorang terhadap suatu 
objek atau seseorang dapat mempengaruhi persepsi. Terdapat tendensi bahwa orang akan berusaha memperoleh lebih banyak informasi tentang objek yang mereka rasakan sangat positif atau negatif. Sehingga semakin banyak informasi yang tersedia tentang suatu objek, semakin lengkap persepsi tentang objek tersebut.

\section{Budaya Organisasi}

Budaya organisasi menurut business dictionary adalah nilai dan perilaku yang berkontribusi pada lingkungan sosial dan psikologis yang unik dari suatu organisasi. Budaya organisasi mencakup harapan, pengalaman, filosofi, dan nilai-nilai organisasi yang menyatukannya, dan diekspresikan dalam citra diri, kerja batin, interaksi dengan dunia luar, dan harapan masa depan. Hal ini didasarkan pada sikap, keyakinan, kebiasaan, dan aturan tertulis dan tidak tertulis yang dikembangkan bersama dari waktu ke waktu dan dianggap sah. Juga disebut budaya perusahaan, itu ditampilkan dalam (1) cara organisasi menjalankan bisnisnya, memperlakukan karyawannya, pelanggan, dan komunitas yang lebih luas,(2) sejauh mana kebebasan diizinkan dalam pengambilan keputusan, mengembangkan ide-ide baru, dan ekspresi pribadi,(3) bagaimana kekuatan dan informasi mengalir melalui hirarki, dan(4) seberapa besar komitmen karyawan terhadap tujuan bersama.

Definisi Schein (1990) dalam Braje dan Galetic (2014) yang sering dikutip tentang budaya organisasi sebagai pola asumsi dasar yang telah ditemukan, atau dikembangkan oleh kelompok dalam belajar untuk mengatasi masalah adaptasi eksternal dan integrasi internal. Tersirat dalam definisi ini bahwa organisasi menetapkan nilai-nilai dan norma-norma sebagai akibat dari bagaimana organisasi telah bereaksi terhadap pengaruh penting dari lingkungan dan insiden di masa sekarang dan masa lalu. Budaya organisasi mencerminkan masalah utama yang dihadapi setiap organisasi dalam menghadapi lingkungan eksternalnya untuk bertahan hidup, tumbuh dan mengelola integrasi internalnya. 


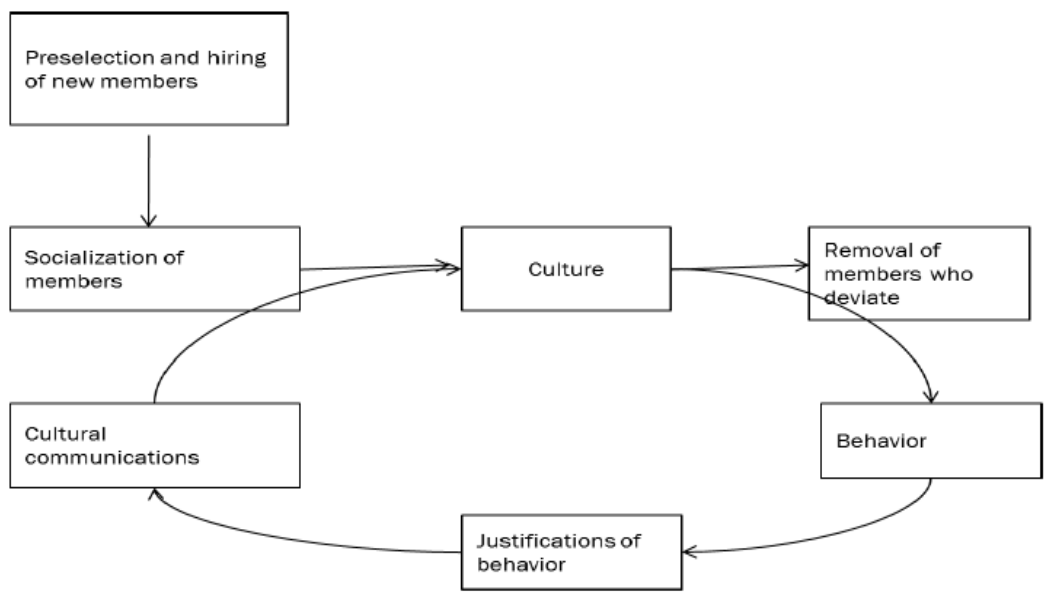

Source: Sathe (1985)

Gambar 2

Culture perpetuation process

Gambar 2 menunjukan proses ketika seorang anggota baru bergabung dalam organisasi kemudian bersosialisasi dengan anggota lainnya dan pada akhirnya mempelajari budaya organisasi yang ada, jika anggota tersebut dapat menyesuaikan diri dengan budaya organisasi maka dia akan berperilaku sesuai dengan budaya organisasi yang ada namun bila tidak maka akan tersingkir dari organisasi. Ketika anggota organisasi telah beradaptasi maka anggota tersebut akan menjustifikasi perilakunya sebagai perilaku yang diinginkan oleh organisasi meskipun budaya organisasi tersebut negatif.

Budaya organisasi terbagi menjadi kuat dan lemah. Suatu budaya dapat dianggap kuat jika norma dan nilai dibagikan secara luas dan dipegang kuat di seluruh organisasi (O'Rilley \& Chatman, 1996 dalam Braje dan Galetic) sehingga menciptakan tingkat konsensus, meskipun dapat juga menjadi masalah konten - jenis nilai yang diadopsi oleh ketegasan perusahaan atau strategis. Budaya yang kuat adalah tuas yang kuat untuk menuntun perilaku; dan membantu karyawan untuk melakukan pekerjaan mereka dengan lebih baik. Perusahaan dengan budaya yang kuat memiliki komitmen yang tinggi terhadap cara pandangnya, sementara budaya perusahaan yang lemah menunjukkan heterogenitas 
dalam keyakinan antara karyawan dan lingkungan. Budaya perusahaan yang kuat yang menyematkan nilai-nilai positif ( salah satunya adalah anti -korupsi ) akan diadaptasi oleh anggota organisasi dan para anggota akan berperilaku sesuai nilai-nilai positif tersebut.

Teori Identitas Sosial (social identity theory) dapat digunakan untuk menjelaskan budaya organisasi. Teori identitas sosial mengasumsikan bahwa individu mengkategorikan dunia sosial mereka ke dalam kelompok (misalnya, individu, tim kerja) dan grup luar (misalnya, bekerja tim di organisasi lain). Mereka mendapatkan harga diri dari identitas sosial mereka sebagai anggota kelompok-dalam,dan konsep-diri mereka tergantung pada bagaimana mereka mengevaluasi kelompok internal mereka relatif terhadap kelompok lain (Tajfel, 1982 dalam Birnberg et al, 2007). Dengan demikian sebagai anggota organisasi, individu berusaha melekatkan identitas sosial dan harga diri mereka dalam kelompok sehingga terdorong untuk melakukan norma-norma, nilai-nilai dan kesepakatan dalam kelompok tersebut.

\section{Penelitian Terdahulu dan Perumusan Hipotesis}

\section{Kualitas Pelaporan Keuangan}

Riset yang dilakukan Cheung et al (2010) tentang kualitas pelaporan keuangan di Australia menunjukan bahwa mayoritas responden yang diwawancarai dan responden lain setuju bahwa perdebatan tentang kualitas pelaporan keuangan muncul oleh serangkaian kegagalan perusahaan. Jika tujuan pelaporan keuangan (dalam bentuk laporan keuangan tujuan umum) adalah penyediaan informasi yang dapat diandalkan untuk pengambilan keputusan, mengapa ada begitu banyak perusahaan ambruk segera setelah rilis laporan tahunan, hal tersebut menimbulkan pertanyaan apakah memang kualitas pelaporan keuangan dapat menggambarkan kondisi senyatanya perusahaan.

Thorntona dan Belski (2010) melakukan studi kualitas pelaporan keuangan pada perusahaan non profit di Amerika Serikat memperoleh hasil bahwa informasi 
keuangan yang buruk kemungkinan akan membatasi kemampuan donor untuk mengidentifikasi secara relative perusahaan yang efisien, mengurangi kemampuan pasar donor untuk bertindak dalam mekanisme tata kelola yang efektif.

Sanders dan Allen (1993) meneliti tentang apakah kualitas pelaporan keuangan pemerintah kota di Amerika Serikat di merupakan signal bagi pemberi kredit. Hasilnya mengkonfirmasi bahwa kualitas pelaporan keuangan pemerintah merupakan signal bahwa kondisi keuangan kota tersebut baik dan mendorong para kreditor untuk memberikan kredit bagi kota-kota dengan kualitas pelaporan keuangan yang bagus.

McDaniel et al (2002) mengeksplorasi beberapa kemungkinan pengaruh aturan yang terkait dengan kualifikasi anggota komite audit dan memberikan bukti pada pertanyaan tentang bagaimana individu menilai kualitas dari pelaporan keuangan perusahaan menggunakan metode eksperimen. Hasil menunjukan bahwa evaluasi ahli (auditor) tentang kualitas pelaporan keuangan lebih terkait erat dengan penilaian mereka tentang karakteristik yang mendasari kualitas pelaporan keuangan.

Kimbro (2002) menguji model yang meneliti hubungan antara variabel ekonomi, budaya dan monitoring (peraturan hukum, kualitas proses akuntansi dan pelaporan keuangan) menemukan bahwa variabel ekonomi (GDP) dan budaya (dimensi budaya Hofstede) berhubungan positif dengan korupsi sedangkan variabel monitoring berkorelasi negative dengan korupsi.

Tujuan pelaporan keuangan bagi organisasi pemerintah bukan hanya ditujukan untuk pengambilan keputusan saja namun juga dalam rangka pertanggungjelasan (accountability) kepada masyarakat. Pelaporan keuangan yang berkualitas dapat menjadi signal bagi masyarakat sebagai principal bahwa pemerintah (agent) telah melaksanakan tugasnya dengan baik.

Berdasarkan pemaparan di atas maka dapat diajukan hipotesis 


\section{H1} : Kualitas pelaporan keuangan berhubungan negatif dengan persepsi tentang

Korupsi.

\section{Peran Mitigasi Budaya Organisasi terhadap Korupsi}

Riset tentang keterkaitan budaya dengan korupsi telah banyak dilakukan namun riset yang mengeksplorasi budaya organisasi dengan korupsi masih terbatas di antaranya riset yang dilakukan oleh Braje dan Galetic (2014) yang menyatakan bahwa bahwa proses pembelajaran dan sosialisasi yang biasanya terkait dengan budaya perusahaan dapat digunakan sebagai titik referensi penjelasan apakah seluruh organisasi terlibat dalam korupsi. Selanjutnya Braje dan Galetic (2014) meneliti tentang budaya organisasi sebagai anteseden korupsi, hasilnya menunjukan semua dimensi budaya yang dieksplorasi dinilai lebih tinggi di antara perusahaan-perusahaan yang tidak memiliki skandal korupsi. Perbedaan tertinggi ditemukan di antara nilai-nilai konsistensi. Konsistensi memberikan sumber pusat integrasi, koordinasi dan kontrol, dan membantu organisasi untuk mengembangkan seperangkat sistem yang menciptakan sistem internal pemerintahan berdasarkan dukungan konsensual.

Kimemia (2013) meneliti hubungan antara budaya organisasi dan korupsi di Kenya, hasilnya menunjukan bahwa terdapat hubungan antara budaya organisasi dan toleransi tindakan korupsi.

Budaya organisasi yang kuat berupa nilai-nilai, norma-norma dan prinsipprinsip yang baik (positif) yang dibagikan secara luas, dipegang oleh seluruh anggota organisasi dan menimbulkan tingkat konsensus yang tinggi akan sangat mempengaruhi perilaku anggotanya.

Berdasarkan pemaparan tersebut maka dapat diajukan hipotesis:

H2 : Budaya organisasi yang kuat berhubungan negative dengan persepsi korupsi. 


\section{Peran Kualitas Pelaporan Keuangan dan Budaya Organisasi dalam memitigasi Persepsi Korupsi}

Teori Psikologi Kognitif digunakan untuk mempelajari bagaimana informasi mempengaruhi proses kognitif individu khususnya penilaian dan pengambilan keputusan. Kognisi terdiri proses mental dan pendapat. Proses mental meliputi: perhatian - alokasi kapasitas pemrosesan terbatas untuk stimulus (informasi); memori , berpikir dan belajar — proses aktif . Keadaan mental mencakup sikap, keyakinan, pengetahuan, dan preferensi.

Penelitian sebelumnya yang meneliti tentang pengaruh informasi terhadap pengambilan keputusan dilakukan oleh Luippold dan Kida (2012) yang menunjukkan bahwa ketika auditor awalnya terkena informasi yang lebih ambigu (baik karena ketidakcukupan atau kompleksitasnya), mereka cenderung untuk mengidentifikasi kesalahan menyebabkan fluktuasi, meskipun mereka memiliki akses ke ambiguitas informasi yang sama yang ditetapkan sebelum membuat penilaian akhir mereka. Berdasarkan penjelasan di atas terlihat bahwa informasi yang diterima sebelumnya akan mempengaruhi pengambilan keputusan.

Bedar dan Bigss (1991) menguji proses penentuan pola dan pembentukan hipotesis untuk kualitas kinerja dalam tugas analitikal. Hasilnya menunjukan bahwa auditor yang membentuk lebih banyak hipotesis di awal, cenderung menemukan pola yang tepat pada saat mengambil keputusan akhir.

Selaras dengan itu, riset yang dilakukan Bhattacharjee dan Machuga (2004) menemukan bahwa auditor cenderung tidak mengubah kualitas judgement apabila telah menentukan terlebih dahulu hipotesis di awal berdasarkan informasi yang telah diterima terlebih dahulu.

Informasi yang diberikan tentang pelaporan keuangan dan budaya organisasi dapat mempengaruhi proses kognitif individu khususnya dalam penilaian dan pengambilan keputusan tentang persepsi korupsi. Lebih lanjut, kualitas laporan 
keuangan yang baik yang didukung budaya organisasi anti-korupsi yang kuat akan menurunkan persepsi tentang korupsi.

Berdasarkan pemaparan di atas maka akan diajukan preposisi:

Prep 1 : Interaksi antara kualitas pelaporan keuangan dan budaya organisasi yang kuat akan memitigasi persepsi tentang korupsi.

\title{
Model Penelitian
}

Model penelitian yang dilakukan dalam riset ini adalah seperti tampak di bawah ini.

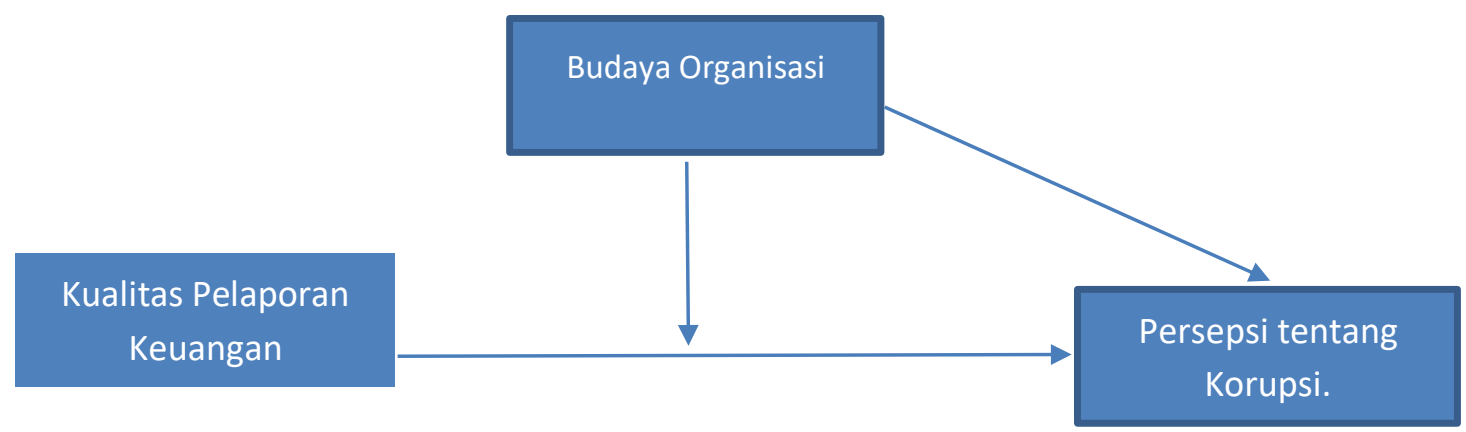

\author{
Gambar 3 \\ Model Penelitian \\ Sumber : Penulis (2019)
}

\section{METODE PENELITIAN}

\section{Desain Penelitian}

Desain penelitian yang digunakan dalam penelitian ini adalah (kausalitas) sebab akibat, karena merupakan penelitian yang menjelaskan pengaruh antara variabel melalui pengujian hipotesis. Penelitian ini dilakukan dengan cara survey untuk memperoleh data primer. Populasi dari penelitian ini adalah aparat sipil negara (ASN) di lingkungan Kota dan Kabupaten di Provinsi Papua. Responden dalam penelitian ini adalah para ASN yang sedang kuliah pada program studi Magister Akuntansi, Magister Keuangan Daerah dan Magister IImu Ekonomi Universitas Cenderawasih yang telah lulus matakuliah Akuntansi 
Sektor Publik dan Keuangan Daerah. Pemilihan sampel ini dilakukan karena para mahasiswa yang merupakan ASN memahami budaya organisasi di lingkungan Pemerintah Daerah tempat mereka bekerja sekaligus juga memahami akuntansi pemerintah dan pengelolaan keuangan daerah sehingga dapat membaca laporan keuangan dan diharapkan dapat memberikan penilaian yang tepat tentang kualitas pelaporan keuangan (McDaniel,2002).

\section{Definisi Operasional dan Pengukuran Variabel}

Variabel dependen dalam penelitian ini adalah korupsi yang didefinisikan sebagai sebagai persepsi individu tentang tindakan penyalahgunaan fasilitas maupun jabatan publik untuk kepentingan pribadi (perceived corruption). Persepsi tentang Korupsi diukur menggunakan Ruch dan Newstrom (1975) ethics scale yang diadaptasi sebelumnya dan juga digunakan dalam penelitian Huang et al (2016), di mana para peserta menilai sejauh mana perilaku tidak etis pada aparatur negara. Tanggapan diberikan menggunakan skala Likert-type 7point mulai dari 1 (sangat tidak mungkin) sampai 7 (sangat mungkin). Skala ini mengandung enam korupsi item, termasuk dua yang berkaitan dengan penyuapan (misalnya, menerima hadiah / nikmat dalam pertukaran untuk perlakuan istimewa) dan empat berkaitan dengan penggelapan (misalnya, menggunakan layanan organisasi untuk penggunaan pribadi).

Kualitas pelaporan keuangan merupakan variable independen dalam penelitian ini. Kualitas pelaporan keuangan diukur menggunakan kuisioner yang telah digunakan sebelumnya oleh Indriasari dan Nahartyo (2008) yang berisi item-item pertanyaan yang mengukur tentang relevansi dan reliabilitas laporan keuangan. Tanggapan diberikan menggunakan skala Likert-type 7-point mulai dari 1 (tidak pernah) sampai 7 (selalu).

Variabel pemoderasi dalam penelitian ini adalah budaya organisasi. Budaya organisasi didefinisikan sebagai seperangkat asumsi atau sistem keyakinan, nilai-nilai dan norma yang dikembangkan dalam organisasi yang dijadikan pedoman tingkah laku bagi anggotaanggotanya untuk mengatasi masalah adaptasi eksternal dan integrasi internal. Variabel ini 
akan diukur menggunakan instrument yang dikembangkankan berdasarkan 7 karakteristik utama budaya organsisasi menurut Robbins (2006) dan tanggapan diberikan menggunakan skala Likert-type 7-point mulai dari 1 (tidak pernah) sampai 7 (selalu).

Untuk menguji hipotesis peran kualitas pelaporan keuangan dan budaya organisasi dalam memitigasi persepsi korupsi maka kami menyusun model regresi berganda sebagai berikut:

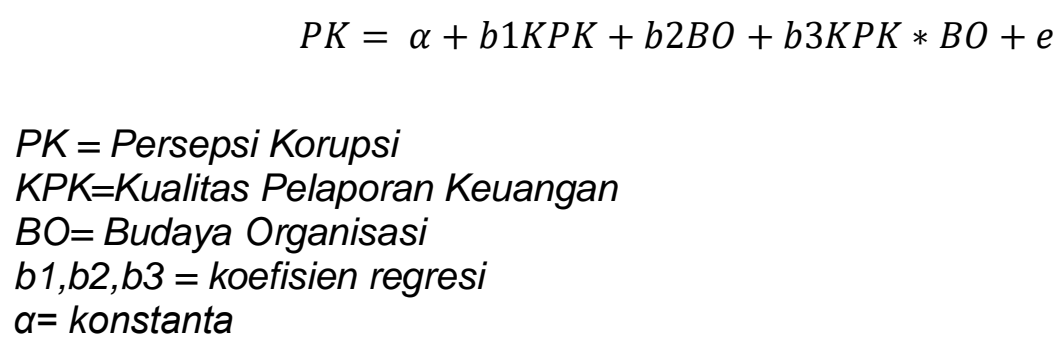

Terdapat dua pengujian yang dilakukan yaitu (1) pengujian pengaruh langsung kualitas pelaporan keuangan maupun budaya organisasi terhadap persepsi korupsi, hubungan tersebut diuji dengan tingkat keyakinan 95\% ( $\alpha=5 \%)$ atau akan terbukti signifikan jika tingkat signifikansi lebih kecil dari nilai $p$-value sebesar 0,05 . (2) pengujian pengaruh moderasi budaya organisasi terhadap persepsi korupsi. Pengujian ini akan dilakukan dengan menggunakan metode interaksi dimana pengaruh variabel pemoderasi adalah signifikan ketika perubahan nilai $F$ dari restricteed model ke full model memiliki nilai $p$-value $<0,05$. Adapun persamaan regresi untuk pengujian pemoderasi adalah:

1. $P K 1=a+b 1 K P K$

2. $P K 2=a+b 1 K P K+b 2 B O$

3. $P K=\alpha+b 1 K P K+b 2 B O+b 3 K P K * B O+e . .(3)$

\section{ANALISIS DATA DAN PEMBAHASAN}

\section{Pemilihan Sampel dan Pengumpulan Data}

Pengumpulan data dalam penelitian ini menggunakan metode mail survey dengan menyerahkan kuisioner secara langsung pada responden dan mengumpulkan secara 
langsung dari responden. Kuisioner disebarkan kepada mahasiswa Magister Akuntansi, Magister Keuangan Daerah dan Magister Ekonomi Universitas Cenderawasih yang merupakan ASN pada PEMDA Kabupaten/Kota di Papua. Kuisioner yang disebarkan berjumlah 100 lembar dengan respon rate sebesar 45 persen namun kuisioner yang layak dianalisis sejumlah 32 kuisioner.

Responden dalam penelitian ini didominasi oleh perempuan yaitu sebesar 66 persen, usia terbanyak antara 32 sampai 40 tahun (56\%) dan dengan latar belakang pendidikan S1 non akuntansi (66\%).

\section{Uji Validitas dan Uji Reliabilitas}

Penelitian ini menggunakan 3 buah kuisioner yaitu kuisioner kualitas pelaporan keuangan yang terdiri atas 13 butir pernyataan, kuisioner budaya organisasi yang terdiri atas yang 20 butir pernyataan dan kuisioner persepsi korupsi yang terdiri atas 17 pernyataan. Untuk memastikan kuisioner tersebut dapat mengukur senyatanya (actually) dan seakuratnya (accurately) maka harus dilakukan pengujian validitas dan reliabilitas terlebih dahulu.

\section{Uji Validitas}

Uji validitas yang digunakan dalam penelitian ini adalah Pearson's Product Moment Correlations Coefficient. Masing-masing instrument variabel diuji validitasnya, yaitu dengan melihat tingkat signifikansinya pada level 0.01 dan 0.05 . Berdasarkan hasil uji validitas terlihat bahwa semua item pernyataan untuk variabel persepsi korupsi adalah valid sehingga tidak ada yang dibuang atau dikeluarkan dari analisis namun pada variabel kualitas pelaporan keuangan dan budaya organisasi masing-masing terdapat satu pernyataan yang tidak valid yaitu pernyataan KPK 1 dan BO 1.

\section{Uji Reliabilitas}

Penelitian ini mengukur konsistensi internal instrumen, yaitu tingkat keterkaitan antar butir pertanyaan dalam suatu instrumen untuk mengukur konstruk tertentu yang digunakan. 
Menurut Sekaran dan Bougre (2016), berdasar nilai Alpha, reliabilitas dapat dikategorikan berikut ini. Nilai Alpha antara 0.8 sampai 1.0 dikategorikan reliabilitas baik, nilai Alpha antara 0.60 sampai 0.79 dikategorikan reliabilitas diterima, dan nilai Alpha kurang dari 0.60 dikategorikan reliabilitas kurang baik. Perhitungan uji validitas dan uji reliabilitas tersebut dilakukan menggunakan SPSS for Windows Versi 21. Setelah butir-butir pernyataan yang tidak valid dikeluarkan selanjutnya dilakukan uji reliabilitas. Hasil uji reliabilitas untuk masingmasing variabel lebih dari 0.5 , hal ini berarti masing-masing variabel yang akan dianalisis adalah reliabel, yaitu terdapat konsistensi diantara butir-butir pertanyaan atau pernyataan dalam instrumen yang digunakan.

\section{Uji Hipotesis dan Pembahasan}

\section{Uji Asumsi Klasik}

Sebelum dilakukan uji hipotesis yang menggunakan metode regresi berganda harus memenuhi beberapa asumsi terlebih dahulu. Oleh sebab itu dilakukan uji asumsi klasik yang terdiri atas uji multikolinearitas, uji autokorelasi, heteroskedastisitas, dan uji normalitas. Hasil uji asumsi klasik menunjukan bahwa untuk pengujian multikolinearitas tidak ada variabel independen yang memiliki nilai Tolerance kurang dari 0,10 yang berarti tidak ada korelasi antar variabel independen yang nilainya lebih dari $95 \%$. Hal tersebut didukung pula oleh nilai VIF dari kedua variabel independen yang tidak lebih dari 10. Jadi dapat disimpulkan bahwa tidak terdapat multikolinearitas antar variabel independen dalam model regresi. Pengujian autokorelasi menunjukan bahwa nilai Durbin-Watson sebesar 1,518 lebih besar dari batas atas (du) 1,3093 maka dapat disimpulkan bahwa tidak terdapat autokorelasi antar variable independen. Grafik pengujian normalitas menunjukan bahwa tidak terdapat pola tertentu yang teratur dimana titik-titik menyebar di atas dan di bawah angka 0 (nol) pada sumbu $Y$ sehingga dapat disimpulkan bahwa tidak terjadi heteroskedastisitas. Uji normalitas dilakukan dengan menggunakan uji statistik non-parametrik Kolmogorov-Smirnov. Hasil pengujian menunjukan bahwa nilai test statistik sebesar 0,493 dengan signifikansi lebih tinggi dari 0,05 sehingga dapat disimpulkan bahwa data residual terdistribusi normal. 


\section{Pengujian Hipotesis}

a. Uji Koefisen Determinasi

Koefisien determinasi digunakan untuk menguji goodness-fit dari model regresi.

Berdasarkan tabel 4.7 adjusted $\mathrm{R}$ Square adalah sebesar 0,139 menunjukan bahwa 13,9 persen variasi persepsi korupsi dapat dijelaskan oleh variabilitas variabel independen, sedangkan siasanya dijelaskan oleh variabel lainnya yang tidak dimasukan dalam model.

b. Uji Pengaruh Simultan (F test)

Tabel 1 Hasil Pengujian Simultan

\begin{tabular}{|c|c|c|c|c|c|}
\hline Model & Sum of Squares & Df & Mean Square & F & Sig \\
\hline Regression & 6.777 & 2 & 3.389 & 3.506 & .043 \\
\hline Residual & 28.026 & 29 & .966 & & \\
\hline Total & 34.803 & 31 & & & \\
\hline
\end{tabular}

Sumber : Data diolah,2019

Uji $\mathrm{F}$ ini digunakan untuk mengetahui apakah variabel kualitas pelaporan keuangan dan variabel budaya organisasi secara bersama-sama mempengaruhi variabel persepsi korupsi. Hasil menunjukan dengan nilai $F$ sebesar 3,506 dan tingkat signifikansi 0,043 lebih kecil dari $p$-value sebesar 0,05 yang berarti bahwa kualitas pelaporan keuangan dan budaya organisasi secara simultan mempengaruhi persepsi korupsi.

c. Uji Pengaruh Langsung (Uji Parsial-t test)

Tabel 2 Hasil Uji $\mathbf{t}$

\begin{tabular}{|c|c|c|c|c|c|}
\hline \multirow{2}{*}{ Model } & \multicolumn{2}{|c|}{$\begin{array}{c}\text { Unstandardized } \\
\text { Coeficients }\end{array}$} & $\begin{array}{c}\text { Standardized } \\
\text { Coeficients }\end{array}$ & \multirow{2}{*}{$\mathrm{t}$} & Sig. \\
\cline { 2 - 5 } & $\mathrm{B}$ & Std.Error & Beta & & 0.015 \\
\hline (Constant) & 5.165 & 1.997 & & 2.587 & .199 \\
\hline $1 \mathrm{KPK}$ & .363 & .276 & .233 & 1.313 & 0.014 \\
\hline BO & -.798 & .306 & -.463 & -2.610 & 0.010 \\
\hline
\end{tabular}

Sumber : Data diolah,2019

Dari hasil uji t di atas dapat disusun persamaan matematis yaitu :

$\mathrm{PK}=5,165+0,363 \mathrm{KPK}-0,798 \mathrm{BO}+\mathrm{e}$ 
Apabila dipaparkan lebih rinci dapat dilihat bahwa variable kualitas pelaporan keuangan tidak berpengaruh signifikan terhadap persepsi korupsi dengan tingkat signifikansi lebih besar dari 0,05 yaitu sebesar 0,199. Sedangkan variable budaya organisasi berpengaruh signifikan dengan tingkat signifikansi sebesar 0,014 karena lebih kecil dari $p$-value sebesar 0,05 .

$d$. Uji Moderasi

Pengujian variabel moderasi menggunakan Moderated Regression Analysis (MRA) yang menggunakan pendekatan analitik dengan mempertahankan integritas simple dan memberikan dasar untuk mengontrol pengaruh variabel moderator. Untuk menggunakan MRA dengan satu variabel prediktor maka harus membandingkan tiga persamaan regresi untuk menentukan jenis variabel moderator (Ghozali,2016), ketiga persamaan tersebut adalah:

1. $P K 1=a+b 1 K P K$

2. $P K 2=a+b 1 K P K+b 2 B O$

3. $P K=\alpha+b 1 K P K+b 2 B O+b 3 K P K * B O+e . .(3)$

Setelah dilakukan análisis maka dapat diperoleh hasil ringkasan regresi sebagai berikut :

1. $P K 1=2,260+0,117 K P K$ dengan t statistik $=1,248$ dan signifikansi 0,222 .

2. $P K 2=5,165+0,363 K P K-0,798 B O$ dengan t statistik $=1,313$; signifikansi $0,199(\mathrm{KPK})$ dan t statistik =-2,610 ;signifikansi 0,014 (BO).

3. $P K=6,964+0,076 K P K-0,147 B O+0,055 K P K * B O$ dengan $\mathrm{t}$ statistik = 0,034, signifikansi 0,973 (KPK); t statistik =-0,424; signifikansi 0,675 (BO); t statistik $=0,130$, signifikansi 0,897 .

Dengan membandingkan ketiga hasil regresi tersebut maka diperoleh informasi bahwa variabel budaya organisasi bukan merupakan variabel pemoderasi 
hubungan antara kualitas pelaporan keuangan (KPK) dengan persepsi korupsi (PK).

\section{Pembahasan}

Riset ini bertujuan untuk menunjukan pengaruh kualitas pelaporan keuangan dan budaya organisasi terhadap persepsi korupsi. Hasil analisis statistik menunjukan bahwa kualitas pelaporan keuangan tidak memengaruhi persepsi para ASN terhadap terhadap korupsi. Pelaporan keuangan pemerintah daerah (PEMDA) bertujuan untuk memberikan pertanggungjawaban kepada masyarakat terkait sumber daya yang dikelola PEMDA, melalui pelaporan keuangan tersebut masyarakat dapat menerima informasi tentang kinerja PEMDA khususnya dalam menjalankan fungsi pemerintahan termasuk pengelolaan keuangan daerah. Pelaporan keuangan yang berkualitas akan menjamin penyajian informasi yang handal atau dapat dipercaya dan berguna dalam pengambilan keputusan bagi para pengguna laporan keuangan pemerintah seperti masyarakat, para wakil rakyat, lembaga pengawas, lembaga pemeriksa, pihak yang memberi atau berperan dalam proses donasi, investasi maupun pinjaman, dan pemerintah. Hasil análisis ynag menunjukan tidak terdapat pengaruh antara kualitas pelaporan keuangan pemerintah daerah dengan persepsi korupsi mencerminkan fenomena menarik yang sedang terjadi di Indonesia. Salah satu indikator kualitas pelaporan keuangan adalah opini hasil audit BPK. Pada tahun 2018 sebagian besar kementerian, lembaga dan PEMDA yang telah mendapatkan predikat wajar tanpa pengecualian (WTP) namun masih terdapat banyak pejabat daerah yang terkena kasus korupsi, hal tersebut diungkapkan Menteri Keuangan Sri Mulyani (https://tirto.id) dan didukung pula oleh dengan data bahwa sejak tahun 2004-2017 terdapat 392 Kepala Daerah tersangkut hukum, jumlah terbesar adalah korupsi sejumlah 313 kasus," diungkapkan Mendagri (www.jawapos.com).

Oleh karenanya PEMDA harus berusaha secara terus menerus memperbaiki pengelolaan keuangan daerah bukan hanya dengan target memperoleh opini WTP namun 
benar-benar memperbaiki pelaksanaan operasional kegiatan dan penerapan system pengendalian internal yang baik sehingga dapat mencegah kecurangan.

Analisis statistik menunjukan bahwa budaya organisasi tidak berperan sebagai variabel pemoderasi namun lebih sebagai variabel independen yang berpengaruh langsung terhadap persepsi dalam hal ini menunjukan pengaruh negatif. Budaya organisasi yang merupakan keyakinan,nilai-nilai dan norma yang diterapkan di dalam organisasi akan menjadi pedoman perilaku bagi anggota organisasi. Ketika sebuah organisasi menerapkan budaya organisasi yang positif maka para anggota organisasi akan menyerap hal tersebut dan menjadi panduan dalam menjalankan pekerjaannya. Budaya organisasi yang positif akan mencegah para anggotanya untuk melakukan kecurangan (korupsi). Hasil riset ini selaras dengan penelitian yang dilakukan oleh Braje dan Galetic (2014) yang meneliti tentang budaya organisasi sebagai anteseden korupsi, hasilnya menunjukan semua dimensi budaya yang dieksplorasi dinilai lebih tinggi di antara perusahaan-perusahaan yang tidak memiliki skandal korupsi dan riset yang dilakukan oleh Kimemia (2013) yang meneliti hubungan antara budaya organisasi dan korupsi di Kenya, hasilnya menunjukan bahwa terdapat hubungan antara budaya organisasi yang negatif dengan toleransi tindakan korupsi.

\section{SIMPULAN, KETERBATASAN, DAN IMPLIKASI}

\section{Simpulan}

Nilai probabilitas (signifikansi) t-test adalah 0,199 untuk pengujian hipotesis 1 , nilai probabilitas (signifikansi) t-test adalah 0,014 untuk pengujian hipotesis 2, sedangkan nilai probabilitas (signifikansi) $t$-test adalah 0,897 untuk pengujian preposisi 1. Tingkat signifikansi tersebut menunjukan bahwa hipotesis 1 dan preposisi 1 ditolak karena tingkat signifikansi lebih besar dari p-value $(0,05)$ atau dengan kata lain disimpulkan bahwa hasil analisis tersebut tidak dapat mendukung hipotesis 1, dan preposisi 3. Sedangkan hipotesis 2 diterima karena tingkat signifikasi lebih rendah dari $p$-value $(0,05)$. 
Hasil pengujian hipotesis 1 menunjukan bahwa kualitas pelaporan keuangan tidak berpengaruh terhadap persepsi ASN tentang korupsi. Hal tersebut menjadi penting untuk dicermati karena seharusnya kualitas pelaporan keuangan yang PEMDA semakin membaik belakangan ini yang ditunjukan dengan semakin banyaknya daerah yang memperoleh opini WTP oleh BPK berbanding lurus dengan persepsi tentang korupsi khususnya yang terjadi lingkungan PEMDA karena opini WTP tidak hanya sekedar tentang kesesuaian dengan prinsip akuntansi yang berlaku umum (PABU) namun juga selaras dengan perbaikan sistem pengendalian internal PEMDA sehingga dapat semakin mengurangi kemungkinan terjadinya kecurangan. Sebaliknya budaya organisasi, berdasarkan hasil pengujian hipotesis 2 berpengaruh negatif terhadap persepsi korupsi. Hal tersebut menunjukan bahwa ketika terdapat nilai-nilai, norma maupun keyakinan yang baik diterapkan di dalam suatu organisasi maka para anggota organisasi akan berperilaku sesuai dengan pedoman tersebut dan pada akhirnya akan mengurangi kemungkinan timbulnya kecurangan. Sedangkan hasil pengujian preposisi 1 yang coba diujikan dalam riset ini menunjukan bahwa budaya organisasi ternyata tidak berperan sebagai variabel pemoderasi yang diasumsikan dapat meningkatkan hubungan antara kualitas pelaporan keuangan dengan persepsi korupsi.

Peneliti menyadari adanya beberapa keterbatasan yang terpaksa tidak dihindari. Beberapa keterbatasan dalam penelitian ini antara lain:

1. Data yang digunakan dalam analisis berasal dari instrumen yang diisi berdasarkan persepsi responden. Hal tersebut akan menimbulkan masalah jika persepsi responden berbeda dengan keadaan sesungguhnya.

2. Jumlah responden yang terbatas karena menggunakan ASN yang sedang kuliah pascasarjana, penelitian selanjutnya diharapkan dapat meningkatkan jumlah respondennya terutama ASN di lingkungan PEMDA.

3. Penggunaan dua variabel independen (kualitas pelaporan keuangan dan budaya organisasi) kurang dapat menggambarkan faktor-faktor yang dapat memitigasi persepsi korupsi hal ini ditunjukan dengan jumlah Adjusted R Square yang rendah, 
penelitian selanjutnya dapat menambahkan variabel-variabel lainnya ke dalam model yang kami gunakan dalam riset ini.

\section{Implikasi}

Penelitian ini, terlepas dari unsur keterbatasan yang dimiliki, diharapkan dapat bermanfaat sebagai bahan acuan dalam pengembangan

1. Bagi ilmu pengetahuan berguna untuk pengembangan riset ilmu akuntansi khususnya akuntansi pemerintah di Indonesia.

2. Bagi Pemerintah sebagai evaluasi dalam meningkatkan kinerja keuangan pemerintah dengan tidak hanya menekankan pada tercapainya opini audit yang baik ( WTP) namun juga dalam pembenahan sistem pengendalian internal pada OPD di PEMDA sehingga dapat mengurangi kemungkinan terjadinya kecurangan (korupsi).

\section{DAFTAR PUSTAKA}

Athanasouli, D., A. Goujard and P. Sklia. 2012. "Corruption and firm performance: evidence from Greek firms". International Journal of Economic Sciences and Applied Research, 5: 4367.

Atuilik, Williams A . 2016. The Relationship Between The Adoption Of International Public Sector Accounting Standards (IPSAS) By Governments And Perceived, Levels Of Corruption International Journal of Current Research Vol. 8, Issue, 05, pp.32052-32070, May.

Benjamin L. Luippold and Thomas E. Kida. 2012. The Impact of Initial Information Ambiguity on the Accuracy of Analytical Review Judgments Auditing: A Journal of Practice \& Theory American Accounting Association. Vol. 31, No. 2 . May 2012 pp. 113-129

Bhattacharjee, Sudip and Susan Machuga. 2004. The Impact of Generating Initial Hypothesis Sets of Different Sizes on the Quality of the Initial Set, and the Resulting Time Efficiency and Final Judgment Accuracy. International Journal of Auditing. 8: 49-65 (2004)

Birnberg, Jacob G., Joan Luft dan Michael D.Shields. 2007. Psychology Theory in Management Accounting Research. Handbook of Management Accounting Research. Elsevier

Braje, Ivana N. Lovorca Galetic. 2014. Corruption And Corporate Culture: Exploring The Connection, International Conference Proceedings, 01/2014

Cheung, Esther. Evans, Elaine;Wrigt, Sue.2010. An Hystorical review of Quality in Financial Reporting in Australia. Public Accounting Review, 09/2010. Volume 22, Issue 2 
Davis, James H. Davis, John A. Ruhe. 2003. Perceptions of Country Corruption: Antecedents and Outcomes. Journal of Business Ethics. 43: 275-288,2003

Faruq, H. And M. Webb, 2013, "Corruption, Bureaucracy And Firm Productivity In Africa". Review Of Development Economics, 17: 117-129.

Gaynor, Lisa M, Andrea Seaton K, Molly Mercer. 2016. Understanding the Relation between Financial Reporting Quality and Audit Quality. Auditing: A Journal Of Practice \& Theory. Vol. 35, No. 4 pp. 1-22

Gaviria, A., 2002, "Assessing The Effects Of Corruption And Crime On Firm Performance: Evidence From Latin America". Emerging Markets Review, 3: 245-268.

Goel, Rajeev K, Ummad Mazhar, Michael A. Nelson. (2016). Corruption across government occupations: cross-national survey evidence. Journal of International Development. 28, 1220-1234 (2016)

Ghozali, Imam. (2016). Aplikasi Analisis Multivariete Dengan Program IBM SPSS 23. Badan Penerbit Universitas Diponegoro.

Gudono. 2017. Analisis Data Riset Eksperimen. Edisi Pertama. BPFE- UGM Yogyakarta

Hartono, Jogiyanto. 2015. Metodologi Penelitian Bisnis. Edisi Enam. BPFE-UGM Yogyakarta.

Heywood, P. M. 2009. 'The Politics of Perception: Use and Abuse of Transparency International's Approach to Measuring Corruption'. Political Studies, 57, 746-767

https://www.jawapos.com/read/2018/02/20/190246/kepala-daerah-paling-banyak-korupsiapbd diakses maret 2018

http://www.bpk.go.id/news/kualitas-laporan-keuangan-pemerintah-daerah-mengalamipeningkatan diakses maret 2018

http://www.businessdictionary.com/definition/organizational-

https://tirto.id/sri-mulyani-klaim-mayoritas-neraca-keuangan-pusat-dan-daerah-wtp-c1a3 diakses tanggal 5 Oktober 2019

Huang, Zhenwei. Wenwen Zheng, Xuyun Tan, Xiaoxiao Zhang, And Li Liu. 2016. Polluted Air Increases Perceived Corruption. Journal Of Pacific Rim Psychology, Volume 10, E13.

Jensen, M.C , Meckling, W. H. (1976) . A Theory of the Firm: Governance, Residual Claims and Organizational Forms (Book). Journal of Financial Economics, Vol 3, No.4

Jonas, Gregory J and Jeannot Blanchet (2000). Assesing Quality of Financial Reporting. Accounting Horizons vol 14 No.3. September 2000, pp 353-363

Kimemia, Douglas. 2013. Organizational culture and corruption: a multiple ase study of nongovernmental organizations in kenya. Virginia Commonwealth University, ProQuest Dissertations Publishing, 2013. 3559622. 
Komite Standar Akuntansi Pemerintahan (2010). Standar Akuntansi Pemerintahan.-

Kimbro, Marinilka B. 2002. A Cross-Country Empirical Investigation of Corruption and Its Relationship to Economic, Cultural, and Monitoring Institutions: An Examination of the Role of Accounting and Financial Statements Quality. Journal of Accounting, Auditing \& Finance, 10/2002, Volume 17, Issue 4

Markovska, Anna; Isaeva, Anna (2007) Public Sector Corruption: Lessons to be learned from the Ukrainian Experience. Crime Prevention and Community Safety, suppl. Special Issue: Countering Fraud in the Public Sector ; London Vol. 9, Iss. 2, (Apr 2007): 118-129.

Mashali, Behzad. 2012. Analyzing the relationship between perceived grand corruption and petty corruptionin developing countries: case study of iran. International Review of Administrative Sciences. 78(4) 775-787

McDaniel, Linda. Roger D. Martin and Laureen A. Maines. 2002. Evaluating Financial Reporting Quality: The Effects of Financial Expertise vs. Financial Literacy. The Accounting Review, Vol. 77, Supplement: Quality of Earnings Conference (2002), pp. 139-167 Published by: American Accounting Association

Nahartyo, Ertambang. 2013. Desain dan Implementasi Riset Eksperimen. Edisi Kedua. UPP STIM YKPN

Pellegrini, L: Gerlagh, R. (2008) Causes of corruption: a survey of cross-country analyses and extended results. Economic of Governance, Volume 9, Issue 3

Robbins, Stephen P. (2006). Perilaku Organisasi, Jakarta: Gramedia.

Sahakyan, N. and K. W. Stiegert, 2012, "Corruption and firm performance". Eastern European Economics, 50: 5-27.

Sanders, George . Arthur Allen. 1993. Financial Reporting Quality and Price Competition Among Nonprofit Firms. Public Budgeting And Finance, 07/1993, Volume 13, Issue 3

Schmidt, Elena D, Yaroslav Pitula. Trust and Perceived Corruption Among Ukrainian Firms. Eastern European Economics, 55: 324-341, 2017

Siegel, G., H. R Marconi. Behavioral Accounting. 1989 . South-Western Publishing Co.

Suwardjono. 2005. Teori Akuntansi: Perekayasaan Pelaporan Keuangan . Penerbit: BPFE Yogyakarta, 2005 (Edisi Ketiga)

Tavits, Margit. 2010. Why Do People Engage in Corruption? The Case of Estonia. Social Forces, 03/2010, Volume 88, Issue 3

Teal, F. and J. McArthur, 2002, "Corruption and Firm Performance in Africa". Economics SeriesWorking Papers: WPS/ 2002-10

Thorntona. Jeremy P., and William H. Belskib.2010. Signaling Government Financial Reporting Quality to Credit Analysts. Applied Economics, 2010, 42, 2699-2713

Sekaran, Uma and Bougre, Roger. 2016. Research Methods for Business -A Skill Building Approach. Wiley. Seventh Edition. 